\title{
Stigma terhadap pasien pasca COVID-19 dan faktor yang mempengaruhinya
}

\author{
Intan Okrima Putri \\ Public Health, STIKES Bhakti Husada Mulia Madiun, Indonesia \\ okrimaintan99@gmail.com \\ *Correspondent Author
}

ARTICLE INFO

Article histor

Received: $21-8-2021$

Revised : 23-08-2021

Accepted : 12-09-2021

\section{Keywords}

Stigma,

Patient Post-COVID

Knowledge

Attitude

The role of community leaders

\section{ABSTRACT}

Stigma is a negative action that can reduce a person's self-confidence. During the COVID-19 pandemic, the stigma can be in the form of refusal of bodies, expulsion of medical staff or ex-communication of patients with confirmed COVID-19 and post-COVID-19 patients. There are 2 Post-COVID-19 patients in Papringan Hamlet. This study aims to find out the influence of knowledge, attitudes, and role of community leaders on the stigma against Post-COVID-19 patients in Papringan Helmet Sidomukti Magetan Regency. This was a cross-sectional study. The population were the people who live in Papringan Hamlet, the sample amount was 97 respondents who used the Slovin formula. The sample criteria were aged 26-45 years, chosen by purposive sampling technique. Data were collected by questionnaires and checklist observations. Data analysis used the logistic regression test. Results: The results of the bivariate analysis test showed that there was an influence a relationship between knowledge (Sig. 0,000), attitude (Sig. $0,000)$, and roles of community leaders (Sig. 0,000) on the stigma against post-COVID-19 patients and multivariate analysis using Binary logistic test indicated there is an influence of knowledge $(O R=16,955)$ to stigma Post-COVID-19 patients in Papringan Hamlet Sidomukti Magetan Regency. The Health Service and community health centres can eliminate the stigma of Post-COVID-19 patients in the community by increasing public knowledge through health education, as well as encouraging the role of religious leaders and community leaders to influence public attitudes so as not to carry out negative stigma against Post-COVID patients.

\section{Pendahuluan}

Sejak tahun 2020 dunia dikejutkan dengan adanya pandemi COVID-19. Penyakit ini dilaporkan pertama kali kepada World Health Organization (WHO) pada akhir tahun 2019 yang mengatakan bahwa terdapat 44 pasien pneumonia yang berat di Kota Wuhan, Provinsi Hubei, China. Diduga penyakit ini berasal dari pasar basah yang menjual ikan, hewan laut dan berbagai hewan lain. Penyebab penyakit ini mulai teridentifikasi pada tanggal 10 Januari 2020 dengan kode genetiknya yaitu virus corona baru $(1,2)$. Virus ini dinamai dengan sindrom pernapasan akut parah coronavirus 2 (SARS-CoV-2) dan dapat menular dengan cepat dari manusia satu ke manusia yang lainnya melalui interaksi secara langsung $(3,4)$.

Berdasarkan data WHO secara global pada tanggal 22 Februari 2021, sebanyak 110.974 .862 orang yang terkonfirmasi positif virus COVID-19 dan 2.460 .792 orang yang meninggal akibat virus ini. Di Indonesia dilaporkan pertama kalinya yaitu 2 kasus pasien yang terkonfirmasi COVID-19 pada tanggal 2 Maret 2020. Hingga pada tanggal 22 Februari 2021 tercatat sebanyak 1.278.653 orang yang terkonfirmasi positif dan 34.489 orang yang meninggal karena terkena virus COVID-19. Peningkatan angka kasus virus COVID-19 terus terjadi setiap harinya, bahkan 
Indonesia mengalami peningkatan harian tertinggi pada tanggal 30 Januari 2021 yaitu sebanyak 14.518 orang yang terkonfirmasi positif(5,6).

Kabupaten Magetan merupakan salah satu wilayah di Provinsi Jawa Timur. Wilayah tersebut tidak luput dari paparan virus COVID-19. Pada tanggal 7 Januari 2021, terdapat 1.030 orang yang terkonfirmasi virus COVID-19. Sedangkan pada tanggal 23 Februari 2021, tercatat sebanyak 2.337 orang yang terkonfirmasi virus COVID-19 dengan angka kematian sebanyak 186 orang. Desa Sidomukti, merupakan salah satu desa di Kabupaten Magetan yang tercatat adanya penderita yang telah sembuh dari virus COVID-19. Hal ini menunjukkan adanya peningkatan kasus virus COVID-19 yang terus terjadi di Kabupaten Magetan. Sebanyak 2 orang pasien COVID19 yang dinyatakan sembuh pada bulan Agustus 2020 di Dusun Papringan (7).

Peningkatan jumlah kasus yang terkonfirmasi virus COVID-19 berpengaruh terhadap kecemasan tiap individu, sehingga dapat menimbulkan berbagai stigma negatif kepada pasien, seseorang yang memiliki resiko tinggi tertular virus COVID-19 seperti dokter, perawat, tenaga kesehatan maupun masyarakat yang berasal dari luar daerah yang beresiko menularkan virus COVID-19. Berdasarkan hasil observasi yang telah dilakukan sebelumnya pada bulan Oktober 2020, stigma negatif yang terjadi di Dusun Papringan yaitu seperti penolakan jenazah positif virus COVID-19, pengusiran staff medis dan pengucilan keluarga pasien yang terkonfirmasi virus COVID-19 maupun yang telah sembuh dari virus COVID-19. Stigma negatif yang dilakukan dapat menurunkan kepercayaan diri penderita dalam berinteraksi serta membatasi akses ke pelayanan kesehatan, sehingga penderita yang mengalami gejala tidak ingin memeriksakan diri(8).

Berdasarkan uraian latar belakang di atas, maka penelitian bertujuan untuk mengetahui faktor yang mempengaruhi stigma masyarakat terhadap penderita pasien Post-COVID di Desa Sidomukti Kecamatan Plaosan, Kabupaten Magetan.

\section{Metode}

Metode yang digunakan dalam penelitian ini yaitu survei analitik, karena penelitian analitik bertujuan untuk mencari hubungan antar variabel dari suatu fenomena. Desain penelitian yang digunakan dalam penelitian ini adalah penelitian kuantitatif dengan desain studi cross sectional.

Populasi dalam penelitian ini adalah masyarakat yang tinggal di Dusun Papringan Desa Sidomukti yang di wilayahnya memiliki pasien Post-COVID. Jumlah populasi berdasarkan kategori usia yang telah ditentukan yaitu sebanyak 129 orang. Kriteria inklusi yaitu kategori usia pada masa dewasa awal dan dewasa akhir (26-45 tahun) dikarenakan pada masa ini seseorang belum mengalami penurunan kemampuan komunikasi sehingga tidak menghambat peneliti pada saat melakukan penelitian dan mengambil data. Dari perhitungan rumus slovin, didapatkan sampel sebanyak 97 orang responden. Sampel dalam penelitian ini adalah sebagian masyarakat yang tinggal di Dusun Papringan Desa Sidomukti Kecamatan Plaosan Kab. Magetan dengan kriteria inklusi dan eksklusiyang telah ditetapkan sebagai sampel oleh peneliti yaitu memiliki tetangga yang telah sembuh dari COVID-19, tinggal di sekitar rumah pasien Post-COVID, dapat berkomunikasi dengan baik. Sedangkan kriteria eksklusi yaitu masyarakat yang tidak bersedia menjadi responden penelitian.

Dalam penelitian ini, peneliti menggunakan instrumen penelitian berupa kuesioner berjumlah 36 soal. Teknik pengambilan sampel menggunakan nonprobability sampling dengan jenis purposive sampling. Jenis data yang digunakan yaitu data primer yang merupakan jawaban dari hasil penyebaran kuesioner dan data sekunder berupa jumlah penduduk berdasarkan usia serta data pasien Post-COVID di Dusun Papringan yang didapatkan dari pihak lain seperti bidan dan perawat Desa Sidomukti, Petugas Kantor Desa Sidomukti, Puskesmas Sumberagung serta jurnal penelitian lain. Pengolahan data menggunakan distribusi frekuensi dan uji regresi logistik. 


\section{Hasil dan Pembahasan}

\subsection{Analisis Univariat}

Tabel 1 menjelaskan mengenai karakteristik dan distribusi frekuensi responden seperti usia, jenis kelamin, pekerjaan, pendidikan terakhir, pengetahuan, sikap, dan peran tokoh masyarakat. Sebagian besar responden berusia 36-45 tahun yaitu perempuan dan memiliki pekerjaan sebagai ibu rumah tangga. Sebanyak $47,4 \%$ memiliki pendidikan terakhir yaitu tamat pendidikan menengah. Distribusi frekuensi responden yang memiliki pengetahuan yang baik dan sikap yang positif lebih banyak dibandingkan responden yang memiliki pengetahuan yang kurang baik dan sikap yang negatif. Sedangkan distribusi frekuensi responden yang menjawab peran tokoh masyarakat memiliki pengaruh lebih banyak dibandingkan dengan responden yang menjawab peran tokoh masyarakat tidak berpengaruh.

Tabel 1.Frekuensi Distribusi Responden

\begin{tabular}{|c|c|c|}
\hline Variabel & Frekuensi & Presentase (\%) \\
\hline \multicolumn{3}{|l|}{ Usia } \\
\hline $26-35$ & 36 & 37,0 \\
\hline $36-45$ & 61 & 63,0 \\
\hline Jenis Kelamin & Data & data $^{1}$ \\
\hline Laki-laki & 18 & 18,6 \\
\hline Perempuan & 79 & 81,4 \\
\hline \multicolumn{3}{|l|}{ Pekerjaan } \\
\hline $\begin{array}{c}\text { Pegawai Negeri/ TNI/ } \\
\text { POLRI }\end{array}$ & 2 & 2,1 \\
\hline Pegawai Swasta & 14 & 14,4 \\
\hline Wiraswasta & 20 & 20,6 \\
\hline Petani & 10 & 10,3 \\
\hline Buruh & 10 & 10,3 \\
\hline Ibu Rumah Tangga & 36 & 37,1 \\
\hline Tidak Bekerja & 5 & 5,2 \\
\hline \multicolumn{3}{|l|}{ Pendidikan Terakhir } \\
\hline Tamat Pendidikan Dasar & 35 & 36,1 \\
\hline $\begin{array}{l}\text { Tamat Pendidikan } \\
\text { Menengah }\end{array}$ & 46 & 47,4 \\
\hline Tamat Pendidikan Tinggi & 16 & 16,5 \\
\hline \multicolumn{3}{|l|}{ Pengetahuan } \\
\hline Buruk & 32 & 33,0 \\
\hline Baik & 65 & 67,0 \\
\hline \multicolumn{3}{|l|}{ Sikap } \\
\hline Negatif & 34 & 35,1 \\
\hline Positif & 63 & 64,9 \\
\hline \multicolumn{3}{|l|}{ Peran Tokoh Masyarakat } \\
\hline Tidak Berpengaruh & 41 & 42,3 \\
\hline Berpengaruh & 56 & 57,7 \\
\hline
\end{tabular}

Pengetahuan merupakan dasar dari seseorang untuk melakukan suatu tindakan. Masyarakat yang memiliki pengetahuan buruk lebih banyak memiliki stigma negatif terhadap pasien PostCOVID. Masih banyak masyarakat yang menganggap bahwa virus ini merupakan virus berbahaya yang dapat mengakibatkan kematian, sehingga mereka merasa takut jika ingin berinteraksi dengan orang yang terkonfirmasi virus COVID-19 maupun orang yang telah sembuh dari virus COVID-19. Namun tidak sedikit masyarakat yang memiliki pengetahuan baik dan memiliki stigma pasien Post-COVID. Hal ini disebabkan karena orang tersebut ingin melindunginya dirinya dan keluarganya, sehingga bertindak secara berlebihan seperti tidak memperbolehkan anggota keluarganya untuk berinteraksi secara langsung dengan pasien Post-COVID. Hasil ini diperkuat dengan hasil penelitian sebelumnya bahwa pengetahuan memiliki hubungan dengan stigma ODHA, dari ketidak pahaman masyarakat mengenai cara penularan HIV dapat menimbulkan 
stigma negatif. Apabila tingkat pengetahuan dari seseorang baik, dapat mendorong sikap seseorang untuk tidak melakukan stigma(9). Begitu pula sebaliknya, apabila pengetahuan dari seseorang buruk akan mendorong sikap seseorang untuk melakukan stigma. Selain itu, juga diperkuat oleh penelitian lain yaitu bahwa kurangnya pengetahuan seseorang dapat membuat kesalahpahaman dan munculnya rasa ketakutan yang berlebih, hal inilah yang dapat mengakibatkan stigma negatif $(10,11)$.

Berdasarkan hasil penelitian yang telah dilakukan di Dusun Papringan Desa Sidomukti Kecamatan Plaosan, Kabupaten Magetan bahwa banyaknya masyarakat yang memiliki sikap negatif menyebabkan adanya stigma terhadap pasien Post-COVID. Tidak sedikit masyarakat yang merasa takut dan malu dengan keberadaan pasien Post-COVID, hal inilah merupakan salah satu faktor penyebab adanya stigma pasien Post-COVID. Hal ini didukung dengan penelitian lain yaitu sikap terhadap stigma yang paling banyak terjadi yaitu sikap yang berhubungan dengan penamaan seseorang yang dianggap berbeda atau memiliki nilai negatif, sikap negatif ini disebut juga stigma "labelling" $(12,13)$. Hasil ini diperkuat dengan hasil penelitian sebelumnya bahwa sikap negatif merupakan hal yang harus dihindari, karena hal ini dapat menyebabkan orang lain sulit dalam memulihkan dirinya dan bangkit dari kegagalan, tidak mendapatkan kebebasan yang sama dengan orang masyarakat lainnya dan dapat menyebabkan keluarga merasa malu dan terganggu(14,15). Sikap merupakan salah satu penyebab yang dapat mengakibatkan stigma. Dalam hal ini, sikap yang ditujukkan lebih ke arah negatif seperti memperlihatkan adanya penolakan terhadap orang yang dianggap berbeda dengan orang lainnya $(16,17)$.

Peran tokoh masyarakat juga memiliki pengaruh terhadap stigma pasien Post-COVID. Hal ini diperkuat berdasarkan hasil penelitian lain bahwa keberadaan tokoh masyarakat memiliki peran penting dalam mengurangi persepsi negatif dan stigma negatif yang ada dikarenakan tokoh masyarakat memiliki pengaruh dan disegani di lingkungannya $(18,19)$. Tokoh masyarakat memiliki berbagai fungsi, tergantung bidangnya masing-masing. Seseorang yang menjadi tokoh masyarakat adalah orang yang memiliki bakat, berwawasan luas, dan memiliki semangat untuk mengajak masyarakat membangun suatu daerah ke arah yang lebih baik(20,21). Sebagian besar masyarakat di Dusun Papringan yang memberikan penilaian terhadap peran tokoh masyarakat tidak berpengaruh dikarenakan tidak adanya contoh perilaku dari tokoh masyarakat dalam mencegah peningkatan virus COVID-19 dan mencegah stigma pasien Post-COVID seperti tidak menggunakan masker pada saat keluar rumah dan saat berinteraksi dengan orang lain, tidak memberikan himbauan kepada masyarakat yang melanggar protokol kesehatan dan tidak memberikan sanksi bagi masyarakat yang melanggar aturan yang telah ditetapan. Hal ini mengakibatkan masyarakat tidak mematuhi protokol kesehatan dan menyebabkan meningkatnya jumlah penderita akibat virus COVID-19.

\subsection{Analisis Bivariat}

Analisis bivariat menunjukkan adanya pengaruh antara pengetahuan, sikap dan peran tokoh masyarakat terhadap stigma pasien Post-COVID.

Tabel 2. Analisis Bivariat Variabel Independen Dengan Stigma Pasien Post-COVID

\begin{tabular}{cccc}
\hline Variabel independen & Sig. & $\boldsymbol{E x p ( B )}$ & $\mathbf{9 5 \%} \boldsymbol{C I}$ \\
\hline Pengetahuan & 0,000 & 43,630 & $(5,608-339,427)$ \\
\hline Sikap & 0,000 & 22,769 & $(5,010-103,488)$ \\
\hline Peran Tokoh Masyarakat & 0,000 & 11,127 & $(3,758-32,709)$
\end{tabular}


Berdasarkan hasil analisis bivariat, didapatkan hasil variabel pengetahuan berdasarkan tabel di atas, terdapat hasil regresi logistik antara pengetahuan dan stigma pasien post COVID dengan nilai sig $(0,000)<$ p-value $(0,05)$ sehingga ada pengaruh pengetahuan terhadap stigma pasien pasca COVID. Nilai $\operatorname{Exp(B)}$ sebesar 43.630 yang berarti bahwa orang yang berpengetahuan buruk memiliki risiko 43.630 kali lebih besar untuk memiliki stigma pasien pasca-Covid dibandingkan dengan orang yang berpengetahuan baik.

Hasil analisis bivariat variabel sikap berdasarkan tabel di atas, terdapat hasil regresi logistik antara sikap dan stigma pasien pasca COVID dengan nilai sig $(0,000)<p$-value $(0,05)$ sehingga ada pengaruh sikap terhadap stigma pasien pasca COVID. Nilai $\operatorname{Exp(B)~sebesar~22.769}$ yang berarti orang yang memiliki sikap negatif memiliki risiko 22.769 kali lebih besar untuk memiliki stigma pasien pasca COVID dibandingkan orang yang memiliki sikap positif.

Hasil analisis bivariat variabel peran tokoh masyarakat berdasarkan tabel di atas, terdapat hasil regresi logistik antara peran tokoh masyarakat dan stigma pasien pasca COVID dengan nilai sig $(0,000)<$ p-value $(0,05)$ sehingga terdapat pengaruh peran tokoh masyarakat terhadap stigma pasien pasca COVID. Nilai Exp (B) 11,127 yang berarti orang yang tidak memiliki peran tokoh masyarakat berisiko 11,127 kali lebih besar terkena stigma pasien pasca COVID dibandingkan orang dengan peran tokoh masyarakat berpengaruh

\subsection{Analisis Multivariat}

Tabel 3. Hasil Variabel in the Equation Tahap II

\begin{tabular}{|l|c|c|c|c|c|c|c|c|}
\hline \multicolumn{1}{|c|}{ Variabel } & \multirow{2}{*}{ B } & \multirow{2}{*}{ S.E } & \multirow{2}{*}{ Wald } & \multirow{2}{*}{ df } & \multirow{2}{*}{ Sig } & \multirow{2}{*}{ Exp. (B) } & \multicolumn{2}{c|}{ CI (95\%) } \\
\cline { 7 - 10 } & & & & & Lower & Upper \\
\hline Pengetahuan & 2,831 & 1,107 & 6,538 & 1 & 0,011 & 16,955 & 1,937 & 148,450 \\
\hline Sikap & 2,083 & 0,861 & 5,850 & 1 & 0,016 & 8,025 & 1,484 & 43,390 \\
\hline $\begin{array}{l}\text { Peran tokoh } \\
\text { masyarakat }\end{array}$ & 1,886 & 0,637 & 8,756 & 1 & 0,003 & 6,591 & 1,890 & 22,980 \\
\hline
\end{tabular}

Berdasarkan hasil analisis multivariat regresi logistik tahap II menunjukkan variabel pengetahuan memiliki nilai sig $(0,011)<$-value $(0,05)$ dengan nilai OR 16,955 . Besarnya pengaruh yang dimiliki, ditunjukkan dengan nilai EXP (B) atau disebut juga Odds Ratio (OR). Variabel pengetahuan memiliki nilai OR 2,831 yang berarti peluang adanya stigma pasien PostCOVID bertambah 2,831 kali dengan adanya pengetahuan buruk. Oleh karena nilai B bernilai positif, maka pengetahuan memiliki pengaruh yang positif dengan adanya stigma pasien PostCOVID.

Variabel sikap memiliki nilai sig $(0,016)<\mathrm{p}$-value $(0,05)$ dengan nilai $0 \mathrm{R} 8,025$. Besarnya pengaruh yang dimiliki, ditunjukkan dengan nilai EXP (B) atau disebut juga Odds Ratio (OR). Variabel sikap memiliki nilai OR 2,083 yang berarti peluang adanya stigma pasien Post-COVID bertambah 2,083 kali dengan adanya sikap negatif. Oleh karena nilai B bernilai positif, maka sikap memiliki pengaruh yang positif dengan adanya stigma pasien Post-COVID.

Variabel peran tokoh masyarakat memiliki nilai sig $(0,003)<p$-value $(0,05)$ dengan nilai OR 6,591. Besarnya pengaruh yang dimiliki, ditunjukkan dengan nilai EXP (B) atau disebut juga Odds Ratio (OR). Variabel peran tokoh masyarakat memiliki nilai OR 1,886 yang berarti peluang adanya stigma pasien Post-COVID bertambah 1,886 kali dengan adanya peran tokoh masyarakat yang tidak berperan. Oleh karena nilai B bernilai positif, maka peran tokoh masyarakat memiliki pengaruh yang positif dengan adanya stigma pasien Post-COVID.

Berdasarkan hasil analisis multivariat, dapat diketahui bahwa variabel pengetahuan adalah variabel yang paling dominan memiliki pengaruh terhadap stigma pasien Post-COVID yang dapat dilihat berdasarkan persamaan regresi logistik yang menunjukkan nilai koefisien regresi (B) yaitu 2,831. Apabila pengetahuan seseorang baik, hal ini akan mendukung adanya 
sikap positif baik dari masyarakat maupun dari tokoh masyarakat setempat. Sehingga tokoh masyarakat juga dapat memberikan contoh yang baik dan mendorong masyarakatnya untuk tidak melakukan stigma terhadap pasien Post-COVID.

\section{Kesimpulan}

Pengetahuan, sikap, dan peran tokoh masyarakat berpengaruh terhadap stigma pasien Post-COVID. Dinas Kesehatan dan puskesmas dapat menghilangkan stigma pasien Post-COVID di masyarakat dengan cara meningkatkan pengetahuan masyarakat melalui pendidikan kesehatan, serta mendorong peran tokoh agama dan tokoh masyarakat untuk mempengaruhi sikap masyarakat agar tidak melakukan stigma negatif terhadap pasien Post-COVID.

\section{Ucapan Terimakasih}

Saya ingin mengucapkan terimakasih kepada STIKES Bhakti Husada Mulia Madiun yang telah membantu dalam membiayai penelitian ini.

\section{Konflik Kepentingan}

Penulis menyatakan jika artikel ini tidak ada konflik kepentingan.

\section{Referensi}

1. Setiawati L, Sariti I, Livana P. Stigma dan perilaku masyarakat pada pasien positif covid19. J Gawat Darurat. 2020;2(2):95-100.

2. Putranto dr TA. Kemenkes Kenalkan Istilah Probable, Suspect, Kontak Erat dan Terkonfirmasi COVID-19 [Internet]. Sehat Negeriku. 2020. Available from: http://sehatnegeriku.kemkes.go.id/baca/rilis-media/20200714/2834469/kemenkeskenalkan-istilah-probable-suspect-kontak-erat-dan-terkonfirmasi-covid-19/

3. Fadli F, Safruddin S, Ahmad AS, Sumbara S, Baharuddin R. Faktor yang Mempengaruhi Kecemasan pada Tenaga Kesehatan Dalam Upaya Pencegahan Covid-19. J Pendidik Keperawatan Indones. 2020;6(1):57-65.

4. Dinas Kesehatan Daerah Istimewa Yogyakarta. Arti Dibalik Nama Covid 19 [Internet]. DINAS KESEHATAN DAERAH ISTIMEWA YOGYAKARTA. 2020 [cited 2021 Jan 9]. Available from: https://www.dinkes.jogjaprov.go.id/berita/detail/arti-dibalik-namacovid-19-2

5. WHO. Coronavirus Disease (COVID-19) [Internet]. WHO. 2020 [cited 2020 Dec 24]. Available from: https://covid19.who.int/

6. Kementerian Kesehatan. Pertanyaan dan Jawaban Terkait COVID-19 Kementerian Kesehatan [Internet]. KEMKES. 2020 [cited 2021 Jan 9]. Available from: https://www.kemkes.go.id/article/view/20030400008/FAQ-Coronavirus.html

7. Dinas Kesehatan Kabupaten Magetan. COVID-19 [Internet]. 2020. Available from: https://covid19.magetan.go.id/

8. Ardani I, Handayani S. Stigma terhadap Orang dengan HIV/AIDS (ODHA) sebagai Hambatan Pencarian Pengobatan: Studi Kasus pada Pecandu Narkoba Suntik di Jakarta. Bul Penelit Kesehat. 2017;45(2):81-8.

9. Saprudin A, Heriana C, Jatiningsih S. Pengetahuan dan Sikap Stigma Mahasiswa Kebidanan 
STIKES KUNINGAN Terhadap Orang Dengan HIV/AIDS (ODHA). J Ilmu-ilmu Kesehat Bhakti Husada Kuningan. 2015;4(2):22-5.

10. Puspita A, Hayati F, Fuadah DZ. Stigma Masyarakat Terhadap Orang Dengan Hiv Aids (Odha). J Ilmu Kesehat. 2017;8(2):151-9.

11. Wulandari ISM, Namah I. Penyuluhan Kesehatan Tentang Hiv/Aids Terhadap Pengetahuan Dan Sikap Pada Siswa Sma Negeri Parongpong Desa Cihanjuang Kecamatan Bandung Barat. J Sk Keperawatan. 2019;5(1):56-62.

12. Martiningsih, Abdul H, Ade W. Stigma Petugas Kesehatan Terhadap Pasien Hiv/Aids Dan Problem Solving. J Kesehat Prima. 2015;I(2):1471-7.

13. Abudi R, Mokodompis Y, Magulili AN. Stigma Terhadap Orang Positif Covid-19. Jambura J Heal Sci Res. 2020;2(2):77-84.

14. Garamina HJ. Hubungan Pengetahuan dan Sikap Masyarakat Terhadap Stigma Penyakit. J Aromed Unila. 2015;2(3):326-32.

15. Yani F, Harahap FSD, Hadi AJ. Stigma Masyarakat Terhadap Orang Dengan HIV/AIDS (ODHA) Di Kabupaten Aceh Utara. MPPKI (Media Publ Promosi Kesehat Indones Indones J Heal Promot. 2020;3(1):56-62.

16. Nirindah R, Prastiwi W, Studi P, Masyarakat K, Kesehatan FI, Surakarta UM. Hubungan Pengetahuan, Sikap dan Persepsi Anggota WPA Tentang HIV/ AIDS dengan Stigma Pada ODHA di Surakarta. 2019; hal 1,5,7.

17. Maharani F. Faktor -Faktor Yang Berhubungan Dengan Stigma Terhadap Orang Dengan Hiv Dan Aids (Odha). J Endur. 2017;2(2):158.

18. Latifa A, Purwaningsih SS. Peran masyarakat madani dalam mengurangi stigma dan diskriminasi terhadap penderita HIV \&amp; AIDS. J Kependud Indones. 2016;6(2):51-76.

19. Rosidin U, Rahayuwati L, Herawati E. Perilaku dan Peran Tokoh Masyarakat dalam Pencegahan dan Penanggulangan Pandemi Covid -19 di Desa Jayaraga, Kabupaten Garut. Umbara. 2020;5(1):42.

20. Rembang, Prisilia. Lasut, J. Kandowangko N. Peranan tokoh masyarakat dalam penanganan masalah sengketa tanah di desa sulu kecamatan tatapaan kabupaten minahasa selatan. 2018;(21).

21. Salamah A, Harmanto. Peran tokoh masyarakat dalam mengungkap kasus korupsi studi kasus desa ploso kecamatan krembung kabupaten sidoarjo. Kaji Moral dan Kewarganegaraan. 2019;1204025403:723-37. 